\title{
AOR
}

Selected Papers of \#AolR2019:

The $20^{\text {th }}$ Annual Conference of the Association of Internet Researchers Brisbane, Australia / 2-5 October 2019

\section{TOO MANY COOKS: TRUSTING NEW VOICES IN ONLINE CULINARY ADVICE}

\author{
Katherine Kirkwood \\ Queensland University of Technology
}

Digital technology is becoming increasingly enmeshed in the practices of everyday life, particularly that of cooking and eating (see Lewis 2018; Kirkwood 2018). The proliferating number of devices and platforms through which users can engage with and disseminate culinary information mean it is becoming increasingly important for users to remain vigilant about the voices and perspectives they turn to for food and nutrition advice.

Previously, culinary celebrities like Jamie Oliver, Nigella Lawson and the like gained their legitimacy through being chefs, restaurateurs or food writers, for example. As this paper will illustrate, culinary personalities with controversial views still have mainstream media traction. However, the ease with which anyone with a digital device and an Internet connection can disseminate culinary information means it becomes more difficult to verify the legitimacy of these identities and their claims. This scenario is pertinent when considering online food information where credibility is increasingly established through followers, likes, and subscribers on social networking platforms.

In examining which online sources are trustworthy, this paper adds to the scholarship that highlights how the growing industrialisation of food led to a loss of food literacy (Pollan 2006; Vileisis 2008) that popular media is attempting to rectify. In relation to digital food media, Lewis $(2018,214)$ argues that "food citizens increasingly require a critical media literacy...". This is especially important considering that consumers are more likely to turn to the media than nutrition professionals for advice (Contois and Day 2018, 16).

This paper questions then how media personalities obtain trust in a foodscape that is becoming increasingly complex as both the number of dietary approaches, as well as avenues for engaging with food media proliferate. Through textual analysis of news, popular commentary, as well as relevant books and films, this paper explores the case Kirkwood, K. (2019, October 2-5). Too Many Cooks: Trusting New Voices in Online Culinary Advice. Paper presented at AoIR 2019: The $20^{\text {th }}$ Annual Conference of the Association of Internet Researchers. Brisbane, Australia: AolR. Retrieved from http://spir.aoir.org. 
studies of Australian celebrity chef Pete Evans and fraudulent wellness advocate, Belle Gibson. In doing so, this analysis highlights differing dynamics in how the two food personalities managed to gain trust. Evans leverages his mainstream media exposure and experience as a chef to establish credibility for his online channels where he explores his somewhat alternative culinary views more extensively. Gibson's reputation meanwhile was established in an opposing fashion where she achieved grassroots fame online for supposedly beating cancer through shunning conventional treatments. In both instances, these culinary personalities were eventually met with skepticism and ridicule. Evans has been criticised for venturing outside his remit as a celebrity chef to offer controversial food and medical advice, and Gibson was prosecuted for misleading consumers after claiming to beat cancer through changing her diet. When media personalities rather than nutrition professionals are the prominent source of culinary information, it is especially important to understand how trustworthiness or authority is established and negotiated.

Pete Evans is an Australian celebrity chef and has mainstream prominence as a judge on the Seven Network's reality cooking program My Kitchen Rules. But his other media ventures make it clear that Evans' is an advocate of the Paleo and Keto diets. Evans starred in a Netflix documentary The Magic Pill (2017) and maintains a YouTube channel The Paleo Way with Pete Evans. Although Evans published extensively with Pan MacMillan, including Paleo and Keto cookbooks, he tends to pursue these subjects more extensively via online, rather than traditional, channels. Arguably, this is in some ways a response to the controversy Evans' approach has sparked in recent years. In 2015 Pan Macmillan stepped away from controversial title Bubba Yum Yum: The paleo way for new mum's, babies and toddlers after health professionals raised concerns regarding the high Vitamin A levels in a bone broth baby formula recipe (Davey 2015b). The title was subsequently published independently as an e-book (Landy 2015).

Unlike Evans who used his recognition via legacy media to leverage his alternative food views online, Belle Gibson gained prominence via Instagram and The Whole Pantry (2013) app. She was beginning to achieve mainstream success with a cookbook of the same name, but her ventures were based on what was revealed to be a fabricated story of using a healthy diet, alternative therapies, and avoiding conventional medicine to survive cancer (Davey 2015a). Toscano (in Douglas 2017), co-author of The Woman who Fooled the World: Belle Gibson's Cancer Con emphasised that "her incredible reach was made possible by a number of intensely modern forces." Toscano (in Douglas 2017) pointed out that "she [Gibson] flourished and developed 200,000 followers without ever having gone through the checks and balances that are provided by traditional media." Even when Gibson began working with Penguin-where the publisher's records show it was warned of potential discrepancies in the supposed cancer survivor's story-Gibson still received \$130,000 advance and Penguin "worked intimately with her for more than a year" (Donelly and Toscano 2016). Gibson's case is interesting because she became prominent via social media and then eluded the gatekeeping processes of Apple and Penguin for so long.

Both of these case studies reinforce Lewis' (2018) argument for critical media literacy. Although such literacy is needed in engagements with both legacy and digital media, the abundance of information available online compared with Web 2.0 and produsage 
(Bruns 2008) logics of participation, shareability and do-it-yourself creativity add another layer of complexity for users attempting to navigate the wide array of culinary approaches in circulation. This paper presents two cases, which are similar in that they promote culinary approaches that have gained the ire of conventional science and medicine, but they are different in that Evans uses online channels as an alternative outlet for his personal views, whereas Gibson first cultivated an online following before moving into more mainstream spaces. Analysis of these cases work to uncover how trust is established, how it can then be broken, and potential consequences for audiences who engage with suspect food information.

\section{References}

Bruns, Axel. 2008. Blogs, Wikipedia, Second Life, and Beyond: From Production to Produsage. New York: Peter Lang.

Contois, Emily and Anastasia Day. 2018. "the History of Food and Public Health" in Food and Public Health: A Practical Introduction, edited by Allison Karpyn, 1-30. New York: Oxford University Press.

Davey, Melissa. 2015a. "'None of it's true': wellness blogger Belle Gibson admits she never had cancer." The Guardian. April 22, 2015. https://www.theguardian.com/australia-news/2015/apr/22/none-of-its-truewellness-blogger-belle-gibson-admits-she-never-had-cancer

Davey, Melissa. 2015b. "Pete Evans paleo for kids cookbook put on hold amid health concerns." The Guardian. March 12, 2015. https://www.theguardian.com/australia-news/2015/mar/12/pete-evans-paleo-forkids-cookbook-put-on-hold-amid-health-concerns

Douglas, James Robert. 2017. "Vehind Belle Gibson's cancer con: 'Everything about this story is extreme." The Guardian. November 13, 2017. https://www.theguardian.com/books/2017/nov/13/behind-belle-gibsons-cancercon-everything-about-this-story-is-extreme

Donelly Beau and Nick Toscano. 2016. "Penguin published Belle Gibson's lies despite 'gaps' in her story in her story." Sydney Morning Herald. September 19, 2016. https://www.smh.com.au/national/penguin-published-belle-gibsons-lies-despitegaps-in-her-story-20160920-grkdj5.html

Kirkwood, Katherine. 2018. "Integrating digital media into everyday culinary practices." Communication Research and Practice 4(3): 277-290.

Landy, Samantha. 2015. "Pete Evans' paleo baby cookbook to be released as e-book after publisher puts printed version on hold over health warnings." Herald Sun. March 16, 2015. https://www.heraldsun.com.au/news/pete-evans-paleo-babycookbook-to-be-released-as-ebook-after-publisher-puts-printed-version-on-holdover-health-warnings/news-story/fc06d6d02c72caec4a7b25b8f8d16bdb 
Lewis, Tania. 2018. "Digital food: from paddock to platform". Communication Research and Practice 4(3): 212-228.

Pollan, Michael. 2006. The Omnivore's Dilemma: A Natural History of Four Meals. New York: The Penguin Press.

Vileisis, Ann. 2008. Kitchen Literacy: How we Lost Knowledge of Where Food Comes from and Why We Need to Get it Back. Washington DC: Island Press. 